\section{Investigating the acoustic signs of
different rock types based on the values \\ Investigating the acoustic signs of
different rock types based on the values of acoustic signal RMS of acoustic signal RMS}

Rudarsko-geološko-naftni zbornik

(The Mining-Geology-Petroleum Engineering Bulletin) UDC: 622.2

DOI: $10.17794 /$ rgn.2020.3.3

Original scientific paper

\author{
Mehrbod Khoshouei'; Raheb Bagherpour'; Mohammad Hossein Jalalian'; Mojtaba Yari ${ }^{1,2}$ \\ ${ }^{1}$ Department of Mining Engineering, Isfahan University of Technology, Isfahan 8415683111, Iran. \\ ${ }^{2}$ Department of Mining Engineering, Faculty of Engineering, Malayer University, Malayer 6571995863, Iran.
}

\begin{abstract}
Recent years have seen a vast increase in the use of acoustic waves in real-time and non-destructive detection and monitoring applications in various industries such as mining. Acoustic signal processing methods can provide accurate and reliable estimates of the condition of a process or material in a highly cost-effective way without interrupting the ongoing operations. This paper investigated whether the class of a rock and its strength properties can be estimated based solely on acoustic signals captured during drilling operations. For this purpose, uniaxial compressive strength (UCS), Brazilian tensile strength (BTS), the Schmidt rebound number (SRN), and longitudinal wave velocity (Pw) of a series of samples of sedimentary, metamorphic and igneous rocks were measured in a rock mechanics laboratory. The samples were then subjected to a drilling test and the acoustic signal propagating in the drilling medium was recorded by an acoustic sensor. After obtaining the time spectrum of the captured signals, their RMS values were calculated and compared with the mechanical properties of the corresponding rock samples. For the rocks tested in this study, the obtained RMS values were in the range of 800 to 1,6oo, and generally increased with an increase in strength and hardness. The RMS values obtained for each class of rocks had their own specific range. For sedimentary rocks, this range was 800 to 1000 , for metamorphic rocks, it was 1000 to 1200 , and for igneous rocks, it was 1400 to 1600 . Given the differences in the range of RMS values obtained from the acoustic signals of drilling, these values can be used in the estimation of rock class and strength properties. These results show that there is significant potential for the future use of this approach in the industry for field identification and classification of rocks, especially in deep drilling operations or when there is little information about the characteristics of the rock being drilled.
\end{abstract}

Keywords:

Acoustic Emission Techniques (AET); Rock Type Recognition; Acoustic signals; Signals RMS; Drilling operation.

\section{Introduction}

Acoustic emissions are the pressure waves generated in a material by the energy released due to deformation, fracture, or other types of failure (Khoshouei and Bagherpour, 2019). As these pressure waves propagate through the material, they can be captured by sensors and analysed to gain insight into the properties of the material (Hopwood and McGogney, 1987). This can be done by various types of sensors, such as ultrasonic sensors. Acoustic emission is known as a reliable means for detecting, predicting, and monitoring the behaviour of a physical process or phenomenon. This method has gained wide acceptance among industrial and scientific communities as a useful non-destructive testing and analysis approach (Yari and Bagherpour, 2018, a). Acoustic waves may appear and propagate in one, two, or three dimensions. The important characteristics of these waves include amplitude, wavelength, frequency,

Corresponding author: Raheb Bagherpour

bagherpour@cc.iut.ac.ir phase, wave energy, sound intensity, and sound pressure. When carefully measured and analysed, each of these characteristics can provide valuable information about the wave source and the propagation medium. As illustrated in Figure 1, the application of acoustic emission techniques in research can be classified into three categories: (i) predicting the state or properties of materials, (ii) monitoring the behaviour of components, processes, or materials, and (iii) detection of phenomena.

In mining and excavation projects, the prediction of factors such as drill bit wear rate, the rate of penetration (ROP), blasting performance (based on rock type and characteristics) and the feed rate of the mineral processing plants is of immense importance for decision making regarding the equipment to use in the operations (Yari and Bagherpour, 2018, b). This highlights the importance of having a method to make such predictions with sufficient precision, reliability, speed, and cost-effectiveness, as the project progresses. Over the years, researchers have developed various methods and criteria for predicting the physical and mechanical properties of 


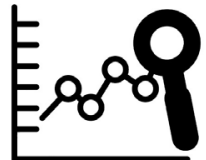

Accurate and real time investigation and prediction of physical and mechanical properties of rock samples are among the most, important activities in various fields such as mining exploration exploitation, designing of rock structures and mineral processing.

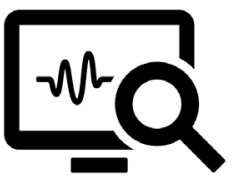

One of the most important activities in various operations is monitoring the behavior of machines and equipment. Real- time monitoring can provide useful results that can lead to better diagnosis and better decision making in projects. Acoustic emission can be very useful in this regard.

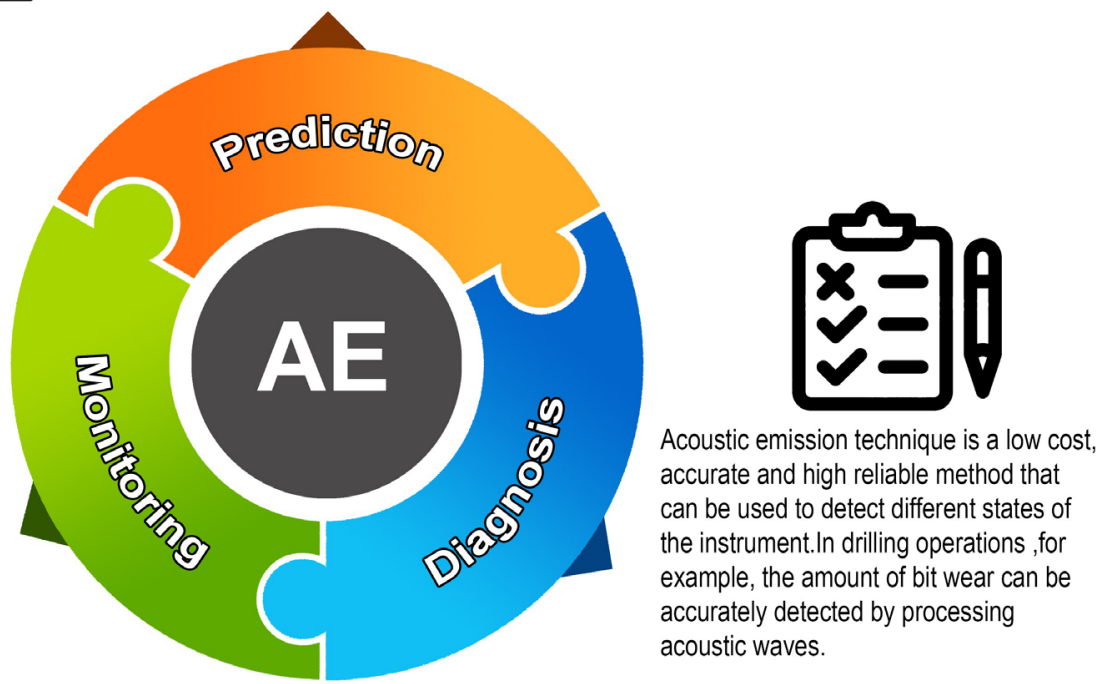

Figure 1: Applications of acoustic emission rocks, each with their own advantages and drawbacks. In recent years, several industries have shown increasing interest in using low-cost and non-destructive variants of the aforementioned methods, including acoustic emission. The use of acoustic emission in the prediction and analysis of the physical and mechanical properties of rocks has been the subject of many studies in recent years. Vardhan et al. investigated the relationship between sound level and rock properties such as compressive strength by performing laboratory-scale tests with a jackhammer (Vardhan et al., 2009). In 2010 Kumar et al. attempted to use sound level to predict the physical and mechanical properties of rocks at the field level (Kumar et al., 2010). In another study, Kumar et al. used multivariate regression to find a relationship between properties such as uniaxial compressive strength, tensile strength, and porosity, and operating parameters such as equivalent sound level, drill bit diameter, drill bit rotation speed, and ROP (Kumar et al., 2011). Bastari et al. developed a method for determining the size of powder particles by the use of signal processing techniques on acoustic emission signals (Bastari et al., 2011). Gra$\mathrm{dl}$ et al. measured the sounds generated during drilling by a microphone and a geophone and then analysed the relationship between the drill bit design and its vibroacoustic properties (Gradl et al., 2012). In a study carried out by Kahraman et al. in 2013, the sound level was used in the prediction of abrasion resistance of rocks (Kahraman et al., 2013). Karakus et al. analysed the spectrum of acoustic signals generated from the impact of the drill bit with the rock during the coring process (Karakus and Perez, 2014). Flegner et al. measured and processed the vibro-acoustic signals generated in the rotary drilling process (Flegner et al., 2014).
Acoustic emission can also be used in monitoring applications. Often, it is much more cost-effective to monitor the behaviour of equipment while they are being used than to let them wear out or break and then stop the operation for repair or replacement. In this area, Leššo et al. attempted to use vibro-acoustic signals to create an integrated information source for monitoring purposes (Leššo et al., 2007). In a study conducted by Marinescu et al., the time-frequency spectrum analysis of acoustic emission signals was proposed as a way to monitor workpiece surface malfunctions in milling operations (Marinescu and Axinte, 2009). Spencer et al. used acoustic emission in the monitoring of froth flotation cells (Spencer et al., 2010). Parsian et al. analysed the sounds generated during the drilling process in frequency and time domains in order to find a way to control and monitor drilling operations (Parsian et al., 2017).

Acoustic emission can also be used as a non-destructive means to quickly estimate the right operating mode, speed, and tools for a given operation and also the amount of energy to be consumed in that operation. Many studies have used acoustic emission for this purpose. For example, Williams and Hagan investigated the relationship between acoustic signals generated in rock and changes in rock cutting conditions (Williams and Hagan, 2006). Xing $Z$ hu et al. observed the low-frequency acoustic signals generated by phenomena such as rockfall, rockslide, thunderstorm, wind turbulence, and erosion (Zhu et al., 2016).

Recent years have seen an increase in the use of acoustic emission techniques in various fields of engineering including geotechnics, drilling, mining engineering, and earth sciences. These techniques offer several advantages over the alternatives. Most importantly, 
assessment with this method can be done swiftly, easily and remotely without stopping the operations. Further, the tests of this method are perfectly non-destructive and can be completed and repeated very rapidly. The development and use of novel methods of acoustic signal processing can greatly contribute to the progress of geoscience and geotechnical experiments and operations in areas such as exploration and prospecting, drilling engineering, mineral processing, and rock mechanics tests.

\section{Acoustic emission}

One can extract a wide range of parameters from the acoustic signal spectrum. Acoustic signals can be analysed in two domains: time and frequency. The important parameters that can be extracted in the time domain include peak, mean spectrum, and RMS (Root Mean Square) of the spectrum. The most important parameter that can be extracted in the frequency domain is the base frequency. In this paper, evaluations were carried out on the time spectrum of signals and RMS.

RMS or root mean square represents the magnitude of the variations of the sound source. In fact, RMS is the ratio that determines the maximum possible quarter in frequency waves with possible variations. This parameter can be a good measure for examining changes in acoustic signals. RMS of an alternating wave can be calculated by Equation 1 (Yamaguchi et al., 2000).

$$
\left.X_{r m s}=\sqrt{\left(\frac{1}{N}\right.} \sum_{i=1}^{N}\left(x_{i}\right)^{2}\right)
$$

Where:

Xrms - is the RMS of signal,

$N \quad$ - is the number of samples,

$X i \quad$ - is the signal amplitude at any given moment.

Figure 2 shows the RMS and peak values of an acoustic signal.

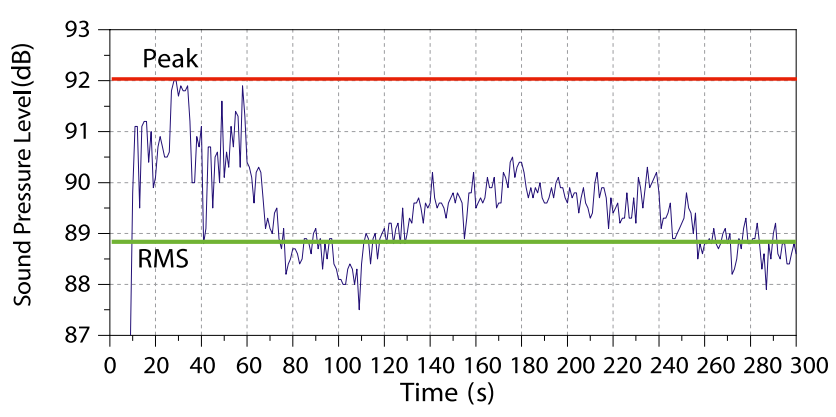

Figure 2: RMS and peak of an acoustic signal

\section{Materials and methods}

\subsection{Laboratory scale Drilling Tests}

Rock samples with different properties are used in the cubic form with dimensions $9 \times 9 \times 9 \mathrm{~cm}$ for drilling tests (Yari et al., 2019). A drill bit was used to perform the drilling and harvesting of acoustic signals generated during drilling operations. The steps of the drilling test are such that, after preparing the samples in the shape and dimensions mentioned, the specimen is fixed by a special clamp. After this stage, the equipment for the recording of the acoustic and vibration signals generated by the drilling operation will be installed and ready, and after the drilling conditions such as the determination of the diameter of the drill bit, the trust force or Weights On the Bit (WOB), the drilling fluid, the speed of the drill bit which are shown in Table 1, the drilling tests begin at each rock sample and begin at the same time as the drilling starts, taking and recording acoustic and vibration signals. Signals are prepared after the completion of the drilling process for subsequent processing. The drilling machine with details, drill bit and rock samples are shown in Figure 3.

Table 1: Drilling tests condition

\begin{tabular}{|l|l|}
\hline Title & Description \\
\hline Weights on bit & $800 \mathrm{~N}$ \\
\hline The rotational speed & 830 RPM \\
\hline Drill bit diameter & $8 \mathrm{~mm}$ \\
\hline Kind of drill bit & Diamond bit Special for hard rocks \\
\hline Drilling fluid & water \\
\hline
\end{tabular}

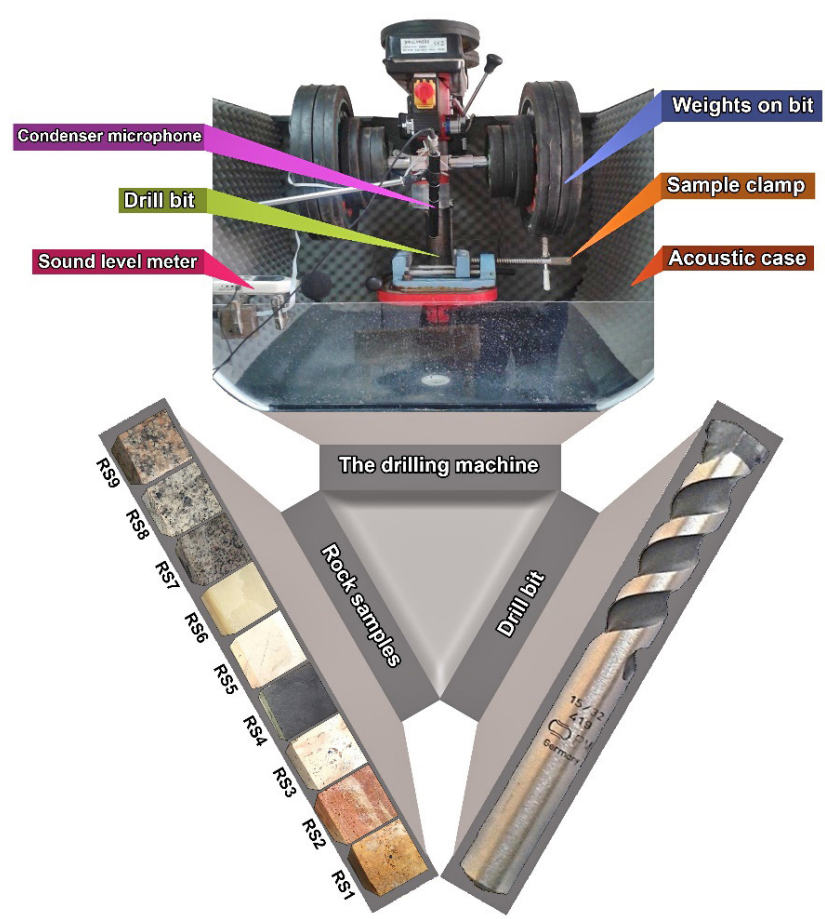

Figure 3: The drilling machine with details, drill bit and rock samples

\subsection{Laboratory tests}

Before conducting drilling operations on the rocks, their mechanical properties including uniaxial compressive strength (UCS), Brazilian tensile strength (BTS), 
Table 2: Tests performed with their standards

\begin{tabular}{|l|l|l|}
\hline $\begin{array}{l}\text { Symbol } \\
\text { of Test }\end{array}$ & Concept & $\begin{array}{l}\text { Summarized description } \\
\text { of test }\end{array}$ \\
\hline UCS & $\begin{array}{l}\text { Uniaxial compressive } \\
\text { strength }\end{array}$ & As stated by ASTM C170 \\
\hline BTS & $\begin{array}{l}\text { Brazilian tensile } \\
\text { strength }\end{array}$ & $\begin{array}{l}\text { As stated by } \\
\text { ASTM-C496-71 }\end{array}$ \\
\hline SRN & $\begin{array}{l}\text { Schmidt's rebound } \\
\text { Hammer test }\end{array}$ & As stated by ISRM \\
\hline Pw & P-wave velocity & $\begin{array}{l}\text { P-Wave Velocity test } \\
\text { described by ISRM (1981) }\end{array}$ \\
\hline
\end{tabular}

Schmidt rebound number, and longitudinal wave velocity $(\mathrm{Pw})$ were determined. The standards used for these measurements are listed in Table 2.

Table 3 shows the type and properties of the rock samples.

Table 3: Type and physical-mechanical properties of the rock samples

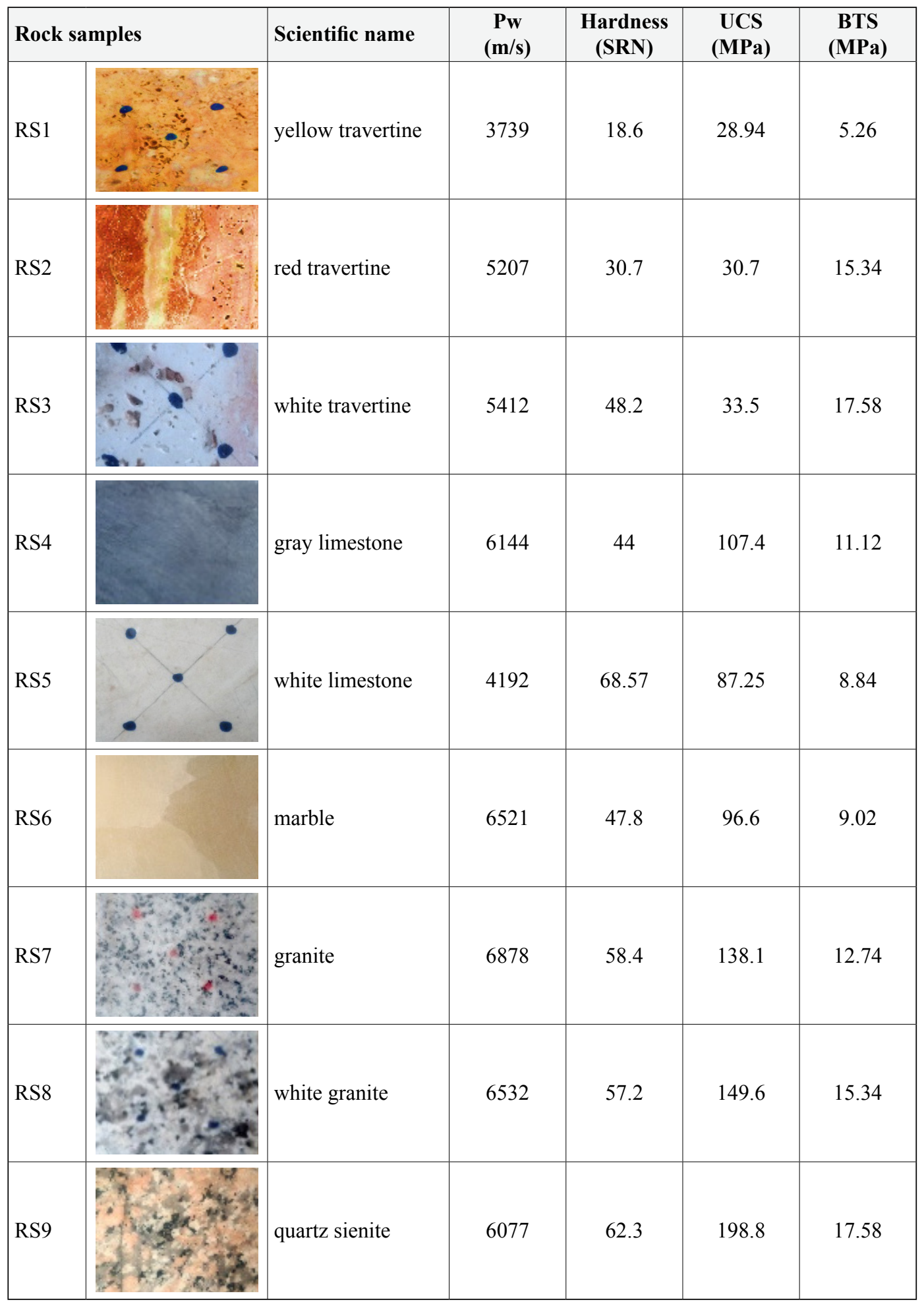




\section{Results}

\subsection{Time Domain of Signals and RMS Values of Signals}

During the drilling operation, the acoustic signals (sound pressure waves) propagating in the medium were recorded by an acoustic wave sensor. Figures 4 to 6 il- lustrate the spectrum of acoustic signals generated during the drilling of each rock sample.

The RMS value of each signal was calculated by Equation 1. The RMS values obtained for the measured acoustic signals are presented in Table 4.

As shown in Figure 7, the RMS values obtained for sedimentary and metamorphic rock samples are quite

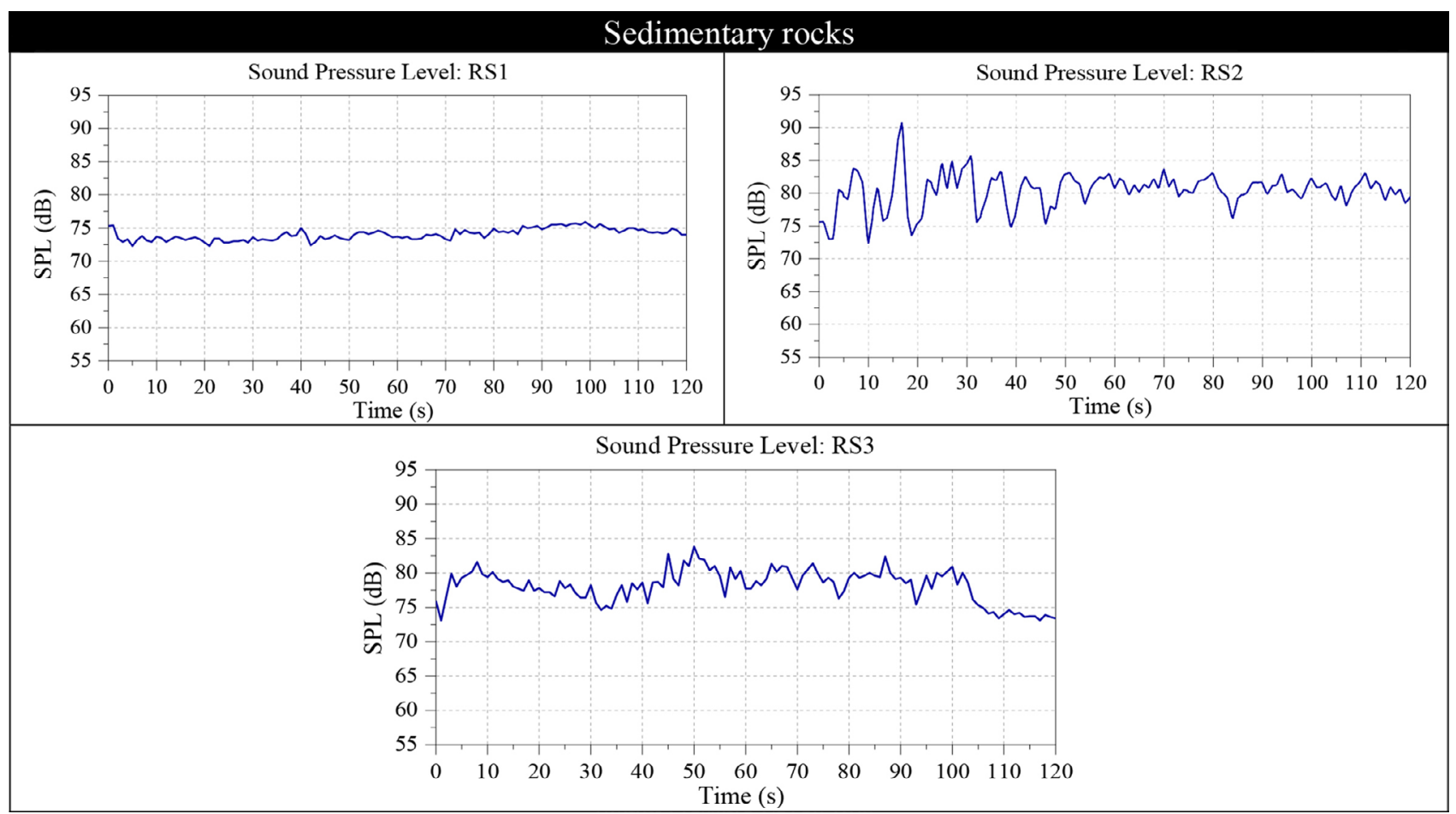

Figure 4: Spectrums of sound pressure levels for Sedimentary rocks

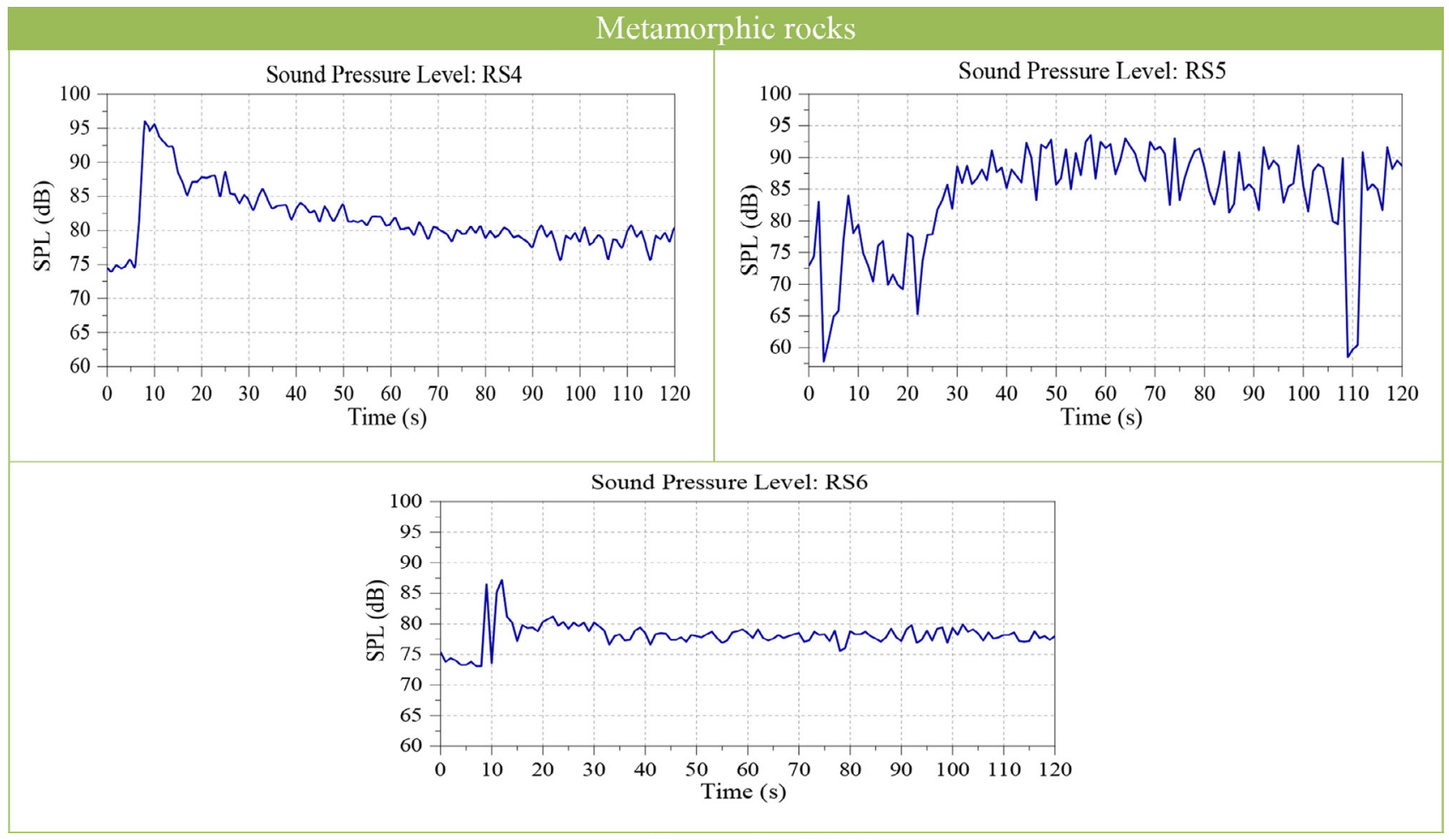

Figure 5: Spectrums of sound pressure levels for Metamorphic rocks 


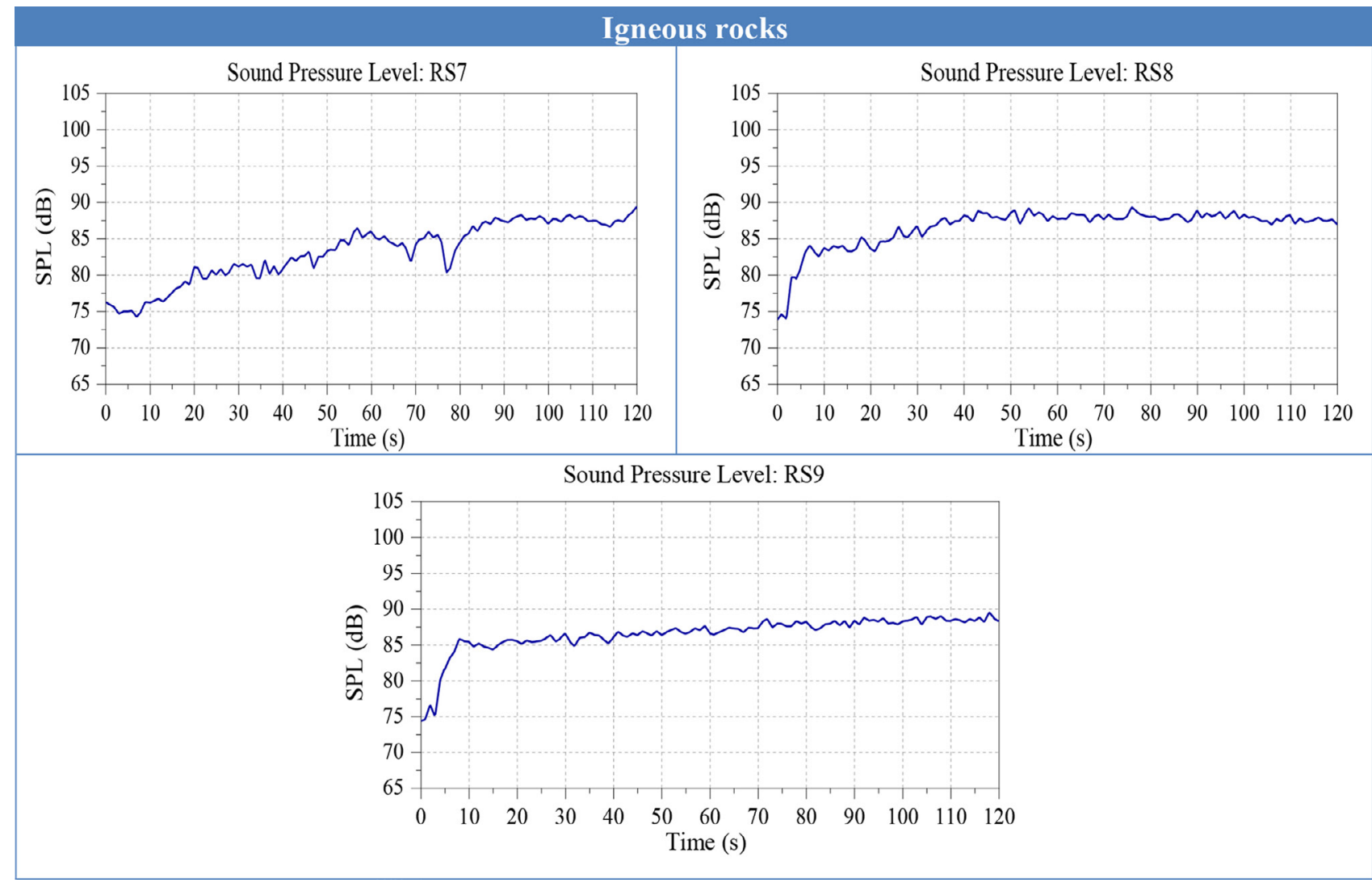

Figure 6: Spectrums of sound pressure levels for Igneous rocks

Table 4: RMS values of acoustic signals recorded during the drilling of rock samples

\begin{tabular}{|l|l|}
\hline Sample number & RMS value \\
\hline RS1 & 855.2008 \\
\hline RS2 & 875.0577 \\
\hline RS3 & 884.1439 \\
\hline RS4 & 1054.12 \\
\hline RS5 & 1063.409 \\
\hline RS6 & 1110.343 \\
\hline RS7 & 1540.503 \\
\hline RS8 & 1452.852 \\
\hline RS9 & 1607.669 \\
\hline
\end{tabular}

similar. This can be attributed to the similarity of these two types of rocks in terms of textural properties. In comparison, igneous rocks have higher RMS values. According to the signals recorded in this study, sedimentary rocks have RMS values of 800 to 1000 , metamorphic rocks have RMS values of 1000 to 1200 , and igneous rocks have RMS values of 1400 to 1600 . Naturally, to find a precise behavioural pattern, one has to conduct repeated tests on a large number of different rock samples, but the purpose of this article was only to examine the possibility of this approach.

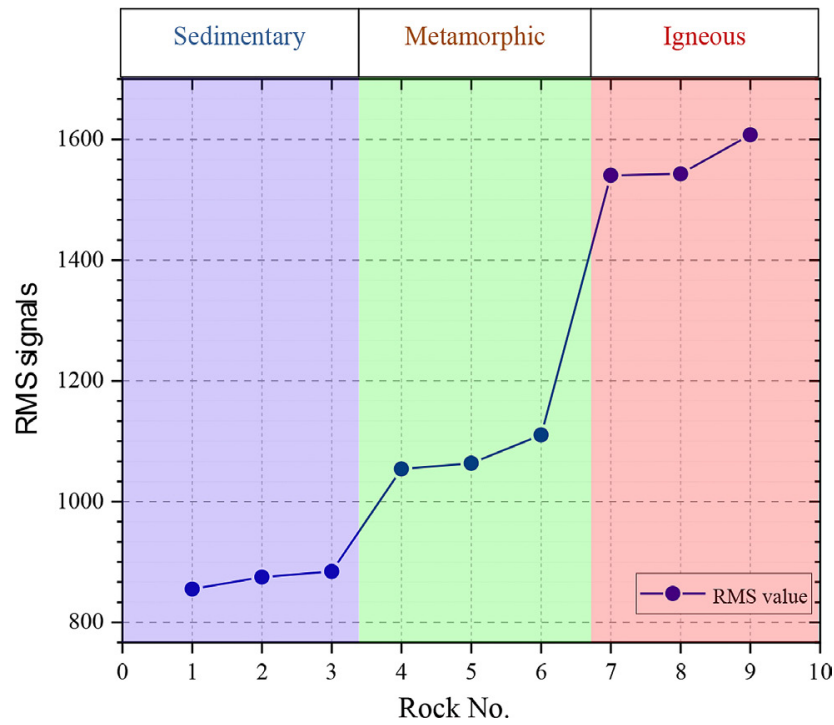

Figure 7: RMS values of the rock samples

\subsection{Investigation of the relationship between the RMS signal value and the mechanical properties of rocks}

This section examines the relationship between the mechanical properties of the tested rock samples and the RMS value obtained by the time spectrum analysis of acoustic signals generated during drilling. The results of this investigation for the relationship between the me- 


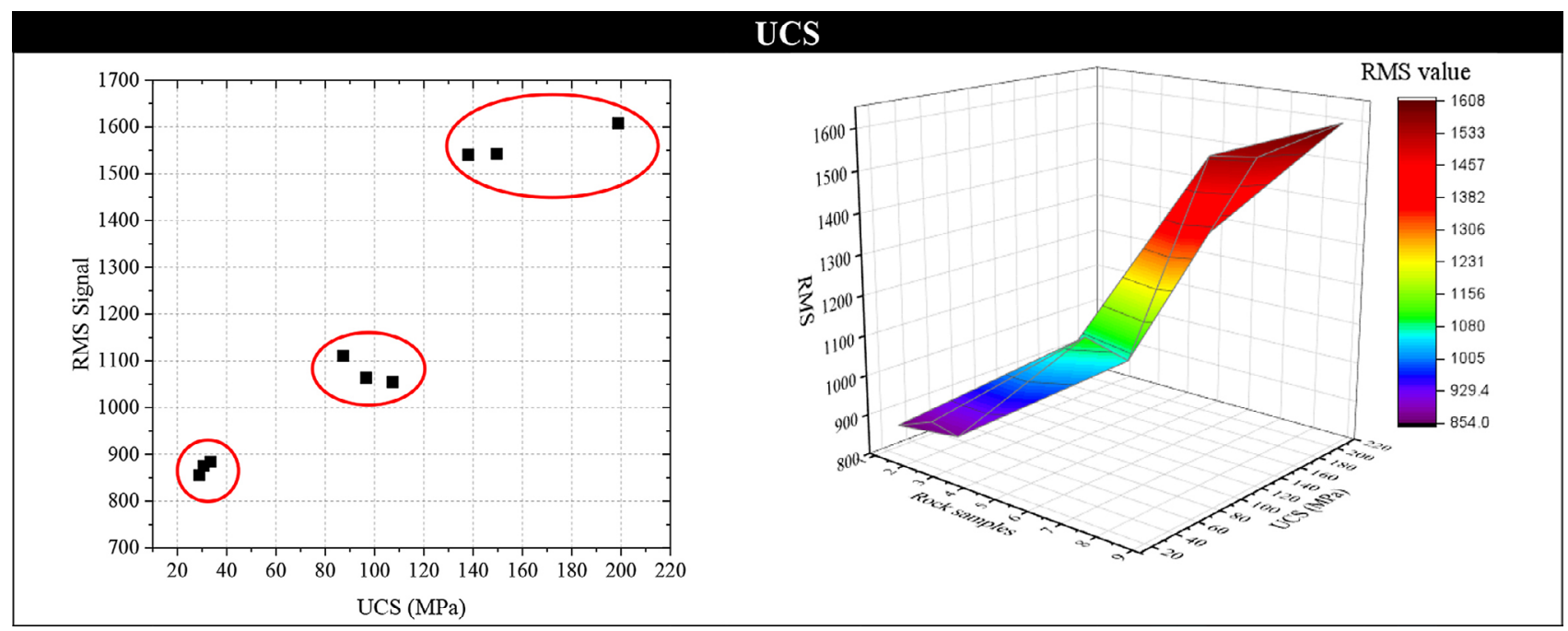

Figure 8: The relationship between UCS values and RMS values

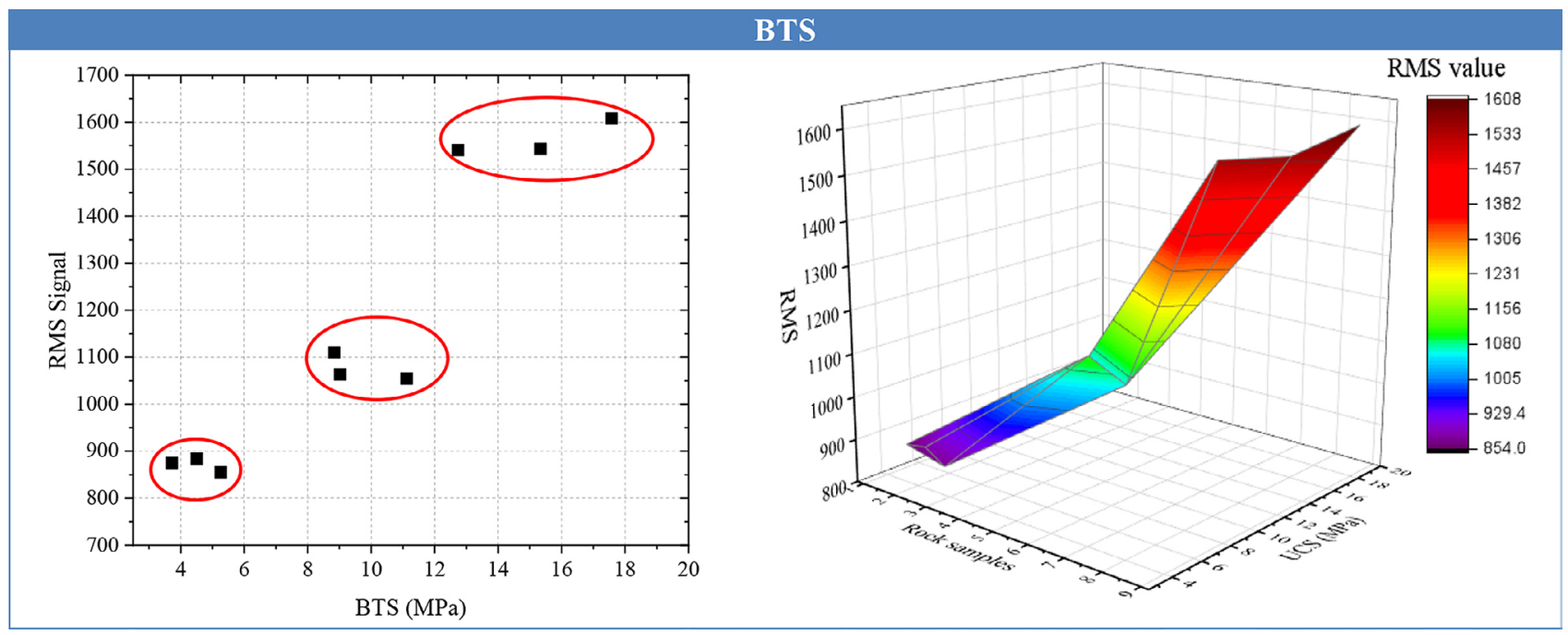

Figure 9: The relationship between BTS values and RMS values

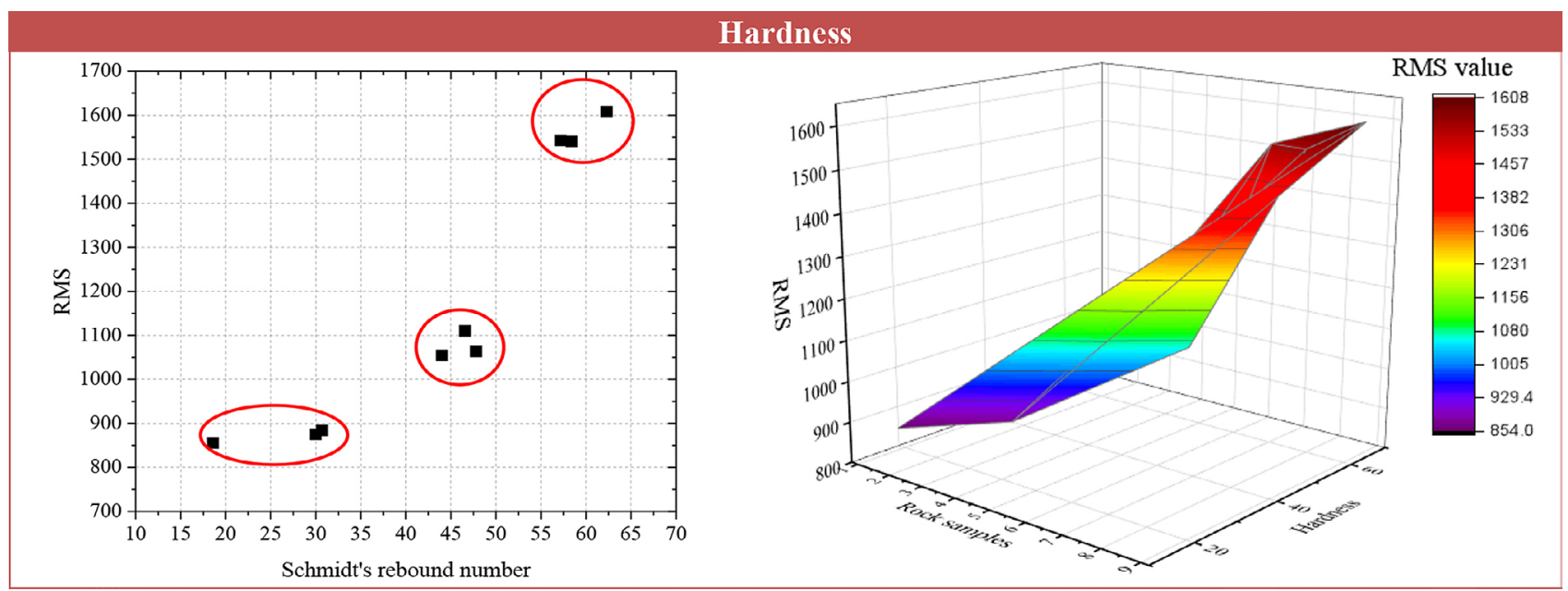

Figure 10: The relationship between Hardness and RMS value

chanical properties of the rocks (uniaxial compressive strength, Brazilian tensile strength, the Schmidt rebound number, and longitudinal wave velocity) and RMS are presented in Figures 8 to 11.
The above diagrams suggest that depending on their mechanical properties, rock samples generate unique acoustic signals during drilling. The RMS value obtained for the signal of each rock seems to be specific 


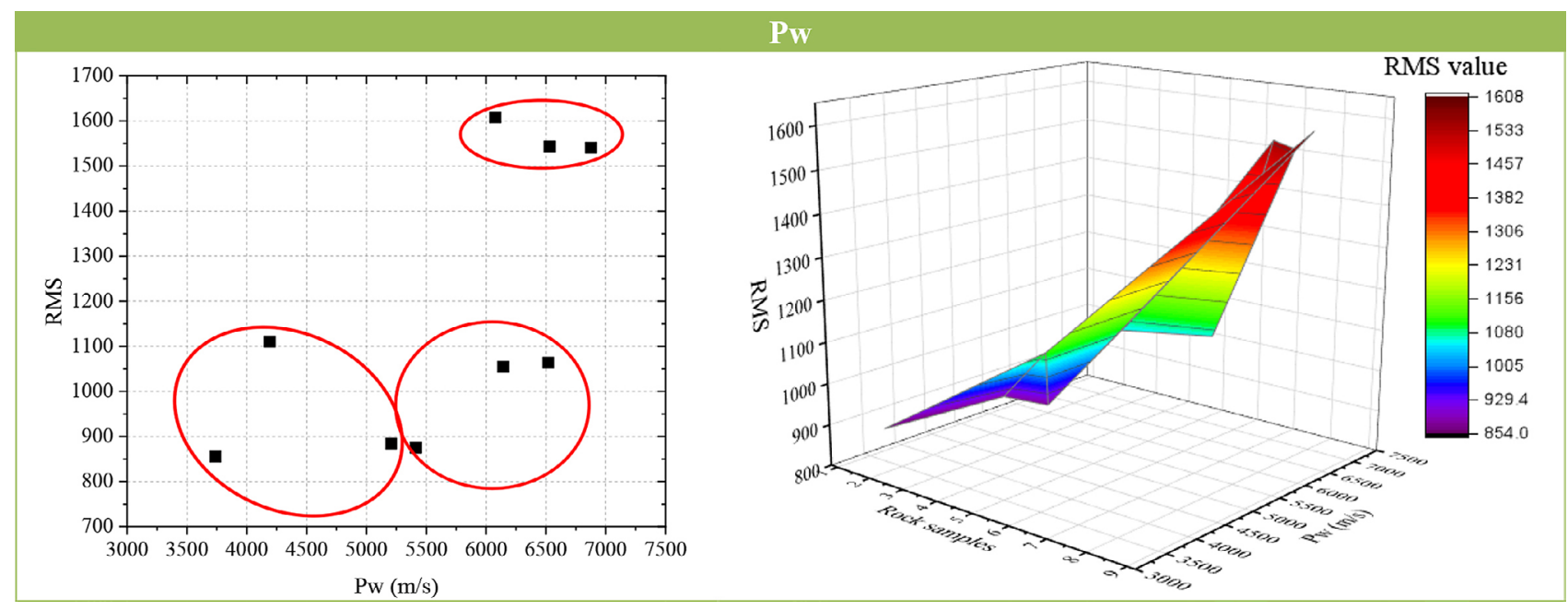

Figure 11: The relationship between Pw and RMS value

enough to be used in the identification of rock type in drilling operations. Considering the UCS, BTS and SRN values illustrated in Figures 8 to 11, there appears to be a significant difference between the three classes of rocks in terms of RMS value based on the 9 tested rock samples. With the physical and mechanical properties of the rocks and the amount of the signals RMS from the sensor embedded on the drilling machine as the input data of the method, the rocks can be classified. One of the limitations of this method is having an accurate acoustic sensor and placing it in a suitable place where the acoustic signals generated from drilling can be accurately measured. These results are promising for the future use of this approach in the industry for the field identification and classification of rock types. The importance of this approach lies in its ability to estimate the strength and class of a rock in a non-destructive method only based on the RMS values obtained from unavoidable drilling operations. This method can be used for realtime determination of operating parameters such as drill bit ROP and drilling fluid flow rate without needing to stop the operation and sample the rock.

\section{Conclusion}

Recent years have seen a dramatic increase in the use of acoustic waves as a means for the real-time and nondestructive detection and monitoring of physical phenomena in various industries. Indeed, there has always been a demand for detection and monitoring methods with the ability to perform their duty accurately, reliably, and cost-effectively without interrupting the monitored operation. This paper examined the possibility of estimating the class and strength properties of a rock being drilled based on the acoustic signals recorded during the drilling operation. For this purpose, 9 samples of sedimentary, metamorphic and igneous rocks were collected and tested in a rock mechanics laboratory to determine their mechanical properties including uniaxial compres- sive strength (UCS), Brazilian tensile strength (BTS), the Schmidt rebound number (SRN) and longitudinal wave velocity $(\mathrm{Pw})$. After these measurements, samples were prepared for drilling tests. During the drilling tests, an acoustic wave sensor was used to record the acoustic signals propagating in the medium or, in other words, the sound pressure level of the entire drilling process. After obtaining the time spectrum of the signal collected from each rock, the RMS value of the signal was calculated and compared with the properties of that rock. The analysis of the acoustic signals captured during the drilling tests showed that the RMS values of these signals fall in the range of 8 to 16 . In general, stronger and harder rocks had higher RMS values, indicating that drilling sound pressure propagates better in harder rocks. Based on the rock samples tested in this paper, in sedimentary rocks, RMS was in the range of 800 to 1000 , in metamorphic rocks, it was in the range of 1000 to 1200 , and in igneous rocks, which had a higher strength and hardness, it was in the range of 1400 to 1600 . Based on the 9 rock samples tested in 3 main groups, the results showed that the RMS values of acoustic signals recorded in the drilling process are specific enough to be used in the identification of the class of the drilled rock and the estimation of its strength properties. These promising results demonstrate that there is significant potential for the use of this method in the industry under field conditions but, in order to increase the reliability of this method and provide a comprehensive model, in the future more rock samples with extensive physical and mechanical properties will be tested and evaluated. In projects involving deep drilling or where there is little information about the characteristics of the area, this method can be used to identify the rock and estimate its properties in real-time based on the acoustic signals recorded by a sensor installed on the rock surface. One of the most important advantages of this method is its simplicity, as it does not need heavy computation nor the addition of expensive and sophisticated equipment and sensors to the 
operation. The purpose of this study was to introduce the approach described above and determine whether RMS values of acoustic signals can be used for rock identification purposes. However, to find a definitive model for determining the type and class of rocks based on RMS values, it is necessary to perform extensive testing on a large number of rock samples.

\section{References}

Bastari, A., Cristalli, C., Morlacchi, R., and Pomponi, E. (2011): Acoustic emissions for particle sizing of powders through signal processing techniques. Mechanical Systems and Signal Processing, 25,3, 901-916.

Flegner, P., Kačur, J., Durdán, M., Leššo, I., and Laciak, M. (2014): Measurement and processing of vibro-acoustic signal from the process of rock disintegration by rotary drilling. Measurement, 56, 178-193.

Gradl, C., Eustes, A. W., and Thonhauser, G. (2012): An analysis of noise characteristics of drill bits. Journal of energy resources technology, 134,1, 31-37.

Hopwood, T., and McGogney, C. (1987): Acoustic emission applications in civil engineering, Nondestructive testing handbook, College of Engineering University of Kentucky Lexington, Kentucky, 325-345.

Kahraman, S., Delibalta, M., Comakli, R. J. F., and Letters, N. (2013): Noise level measurement test to predict the abrasion resistance of rock aggregates. 12,04, 1350021.

Karakus, M., and Perez, S. (2014): Acoustic emission analysis for rock-bit interactions in impregnated diamond core drilling. International Journal of Rock Mechanics Mining Sciences, 68, 36-43.

Khoshouei, M., and Bagherpour, R. (2019): Application of Acoustic Emission (AE) in mining and earth sciences: a review. Rudarsko-geološko-naftni zbornik (The Mining-Geological-Petroleum Engineering Bulletin), 34,4, 19-32.

Kumar, B. R., Vardhan, H., and Govindaraj, M. (2010): Estimating rock properties using sound level during drilling: field investigation. International Journal of Mining and Mineral Engineering, 2,3, 169-184.

Kumar, B. R., Vardhan, H., and Govindaraj, M. (2011): Sound level produced during rock drilling vis-à-vis rock properties. Engineering geology, 123,4, 333-337.
Leššo, I., Flegner, P., Pandula, B., and Horovčák, P. (2007): New principles of process control in geotechnics by acoustic methods. Metalurgija, 46, 3, 165-168.

Marinescu, I., and Axinte, D. (2009): A time-frequency acoustic emission-based monitoring technique to identify workpiece surface malfunctions in milling with multiple teeth cutting simultaneously. International Journal of Machine Tools Manufacture, 49,1, 53-65.

Parsian, A., Magnevall, M., Beno, T., and Eynian, M. (2017): Sound Analysis in Drilling, Frequency and Time Domains. Procedia CIRP, 58, 411-415.

Spencer, S. J., Bruniges, R., Sharp, V., Catanzano, V., Roberts, G., Bruckard, W. J., and Davey, K. (2010): Acoustic emission monitoring of froth flotation: The XXV International Mineral Processing Congress. AUSIMM, Melbourne, 3489-3500.

Vardhan, H., Adhikari, G., and Raj, M. G. (2009): Estimating rock properties using sound levels produced during drilling. International Journal of Rock Mechanicsand Mining Sciences, 46,3, 604-612.

Williams, E., and Hagan, P. (2006). Observations on the variation in acoustic emissions with changes in rock cutting conditions: The Coal Operators' Conference, 93-103.

Yamaguchi, T. J., Soma, M., Ishida, M., Watanabe, T., and Ohmi, T. (2000): Extraction of peak-to-peak and RMS sinusoidal jitter using an analytic signal method: 18th IEEE VLSI Test Symposium, 395-402.

Yari, M., and Bagherpour, R. (2018a): Implementing Acoustic Frequency Analysis for Development the Novel Model of Determining Geomechanical Features of Igneous Rocks Using Rotary Drilling Device. Geotechnical Geological Engineering, 36, 3, 1805-1816.

Yari, M., and Bagherpour, R. (2018b): Investigating an innovative model for dimensional sedimentary rock characterization using acoustic frequency analysis during drilling. Rudarsko-geološko-naftni zbornik (The Mining-Geological-Petroleum Engineering Bulletin), 33, 2, 17-25.

Yari, M., Bagherpour, R., Khoshouei, M. (2019): Developing a novel model for predicting geomechanical features of carbonate rocks based on acoustic frequency processing during drilling. Bulletin of Engineering Geology and the Environment, 78,3, 1747-1759.

Zhu, X., Xu, Q., Zhao, Z., and Li, T. (2016): Low frequency acoustic signals associated with rock falls, thunderstorms, and wind turbulences in field environment. Applied Acoustics, 112, 131-139. 


\section{SAŽETAK}

\section{Istraživanje zvučnoga zapisa u različitim vrstama stijena na temelju vrijednosti RMS zvučnoga signala}

Proteklih godina ostvaren je velik napredak u uporabi zvučnih valova kao trenutačne i neinvazivne metode opažanja i praćenja različitih operacija u rudarstvu i drugim industrijskim granama. Obradba zvučnih signala može omogućiti točnu i pouzdanu procjenu uvjeta procesa ili materijala na ekonomski vrlo isplativ način te bez prekidanja tekućih radova. Ovdje je prikazano ispitivanje sa svrhom mogućnosti procjene vrste i čvrstoće stijene isključivo uporabom zvučnih valova, a tijekom bušenja. Izmjereno je na nizu uzoraka taložnih, metamorfnih i magmatskih stijena vrijednosti jednoosne tlačne čvrstoće, brazilskoga testa vlačne čvrstoće, Schmidtova odskoka i brzine longitudinalnih valova. Zatim su uzorci podvrgnuti testu bušenja i širenja zvučnih valova u bušenome uzorku koji su i snimani. Dobivena je vremenska raspodjela takvih signala, a izračunane su njihove RMS vrijednosti i uspoređene su s mehaničkim svojstvima odgovarajućih stijenskih uzoraka. Kod stijena obrađenih ovim istraživanjem vrijednost RMS-a kretala se između 8oo i 1600 , a općenito je rasla s povećanjem čvrstoće i tvrdoće. Vrijednosti RMS-a prikupljene su za svaku klasu stijena u specifičnome intervalu. Kod taložnih on je iznosio 800 - 1000, metamorfnih 1000 - 1200 i magmatskih 1400 - 16oo. Razlike u vrijednostima RMS-a dobivene iz zvučnih signala generiranih bušenjem mogu se koristiti za procjenu vrste i čvrstoće stijena. Rezultati pokazuju kako takav pristup ima znatan potencijal za buduću uporabu kod terenskoga prepoznavanja i razvrstavanja stijena, posebno kod dubokih bušenja, a pogotovo u slučajevima kada je takvim bušenjima prikupljeno malo podataka.

\section{Ključne riječi:}

odašiljanje zvučnih valova, prepoznavanje vrste stijena, zvučni signali, RMS, bušenje

\section{Authors contribution}

Dr. Raheb Bagherpour performed the design and implementation of the research, Mehrbod Khoshouei, Mohammad Hossein Jalalian and Mojtaba Yari contributed to the analysis of the results and to the writing of the manuscript. 